\title{
Death Image in Divine Meditations of John Donne
}

\author{
Dini Zhang \\ English Department of Literature and Law School of Sichuan Agricultural University, Ya'an, Sichuan Province, China \\ Email: Zhangdini0000@126.com \\ Dingming Wang \\ English Department of Literature and Law School of Sichuan Agricultural University, Ya'an, Sichuan Province, China \\ Email: wangdingming@163.com
}

\begin{abstract}
As an important topic, different people hold different opinions and attitudes towards death according to their world views and believes. In his Divine Meditations, John Donne discusses death with others topics. In this sequence, death appears in different aspects. With different description of death, Donne tries to find a solution to conquer and defeat death. Quite different from the popular opinion in Renaissance, the poetry can immortalize a person; he holds a Christian's belief that through the firm belief of God, man can defeat death.
\end{abstract}

Index Terms - John Donne, death, divine meditations, holy sonnets

John Donne is a representative of Metaphysical School in English literature. Sir Herbert Grierson holds that conceits and wits were common in Elizabethan poetry, but Donne was better in this skill (qtd. in Ford, 1957, p. 106). Samuel Johnson criticized wit as "the most heterogeneous ideas are yoked by violence together" (qtd. in Abrams, 1993, p. 2419). Anyhow, there is a clean logic on image of Donne's poems (Brooks, 1947, p. 211).

Donne uses many images to depict what is in his mind. In sonnet 10 of Divine Meditations, John Donne strictly speaks out "Death thou shalt die" (14). With his "headlong energy of language" (Winny, 1981, p. 36), Donne expresses a wish of human being - defeating death. Since man is conscious of life, he is frustrated with the problem of death. In order to avoid death and live an immortal life, man tries every way to conquer death, both material and spiritual. In Renaissance, many people in England believe that the poetry can make a person eternal. As a Christian and a priest, Donne holds the Christian belief of death. In many of his poems, he meditates on death. In the sequence of Divine Meditations, together with other topics, he also discusses death. Death appears in some poems, and reflects what he thinks about it as a Christian. No doubt it is the blood of Christ which shows mercy of God that can save man. This idea is not new, but the sequence of Divine Meditation has some interior connections and reveals the logic of Donne.

In his lifetime, Donne published only five poems. Most of his poems were collected and published after his death by editors. So this sequence of 19 sonnets is grouped by editors. Clearly, it is not the original idea of Donne. Different editors give it different names. It is entitled Divine Meditations by Smith (1982, p.307), and sometimes is named Holy Sonnets (Abrams, 1993, p. 1097; Bush, 1962, p. 136). Here, the sequence of poems is called Divine Meditations according to the book, John Donne: The Complete English Poems, used in this article. And the order of the sonnets is also followed the order in the book mentioned above. The composition date of these poems is still open to debate. When Donne's poems were first published in 1633, 12 poems were included. They were sonnet 2, 4, 6, 7, 9, 10, 11, 12, 13, 14, 15,16 . In version of 1635 , four sonnets, $1,3,5,8$, were added. The last three sonnets, 17, 18, 19, appeared in the Westmoreland MS, and were published in 1899 (Smith, 1982, p. 624). Many critics agree with Professor Helen Gardner's opinion. She asserts that the first twelve sonnets were written in the first half of 1609, the four sonnets the later half of 1609. The last three sonnets were written during 1617-19. (qtd. in Bush, 1962, p. 136) She also divides 19 sonnets into four groups. The first group has sonnet 2, 4, 6, 7, 9, 10, and talks about death and last judgment. The second group consists of sonnet 11,12,13,14,15,16, and focuses on God's love of man and the love of man owes to God and his neighbour. The third group is the four sonnets added in 1635 edition. It is penitential and focuses sin and tears for sin. The last three sonnets are sonnet discovered in 1899 and there is no connection among them. (qtd. in Smith, 1982, p. 625) Such category helps to know that death is an important topic in the sequence of Divine Meditations. As the description of death appears not only in the first group, but also in other poems, the discussion of death is not limited in the first group, but extends to other poems concerning it. Accordingly, they are sonnet 1, 4, 5, 6, 7, 9, 10, 11, $12,16,17$. Within those poems, the notion of death changes from one to another. It shows that Donne is a faithful Christian and the interior logic in it.

Death is a topic for everyone. Since man is conscious of his existence, he is aware of his death, dissolution of himself. Heidegger (1999) has said "Being towards death" (p. 277). Much earlier than Heidegger, Donne said, "I run to death, and death meets me as fast" (sonnet 1,3 ). He is conscious that he is stepping towards death one day after anther. It is an unknown end. No one will protest the idea that man is stepping to death since his birth. Because no dead people comes 
back to life to tell others what kind of image death is, no man in his lifetime has a clear picture of death except description of forefathers or his imagination. In ancient Rome, the Romans used wax to make a mask of their forefathers called death mask (Stokstad, 1995, p. 243). But they only had the mask of dead people not the mask of death itself. Though there is no actual image of death, it is still described with some characters. Often, it associates with some symbols, such as skeleton, hooded cloak, sword, scythe, sickle or hour-glass (Car-Gomm, 1995, p. 77). Skeleton is the bones of dead people; hooded cloak represents the darkness which associates the death; sword kills people; scythe, sickle, or hour-glass is the symbol of time which destroys all things. Those things represent the results of death, or the destructive forces. Not only limited in the things mentioned above, death also comes along with all dissolution powers.

Though death is so fearful, man tries to conquer it in his limited abilities. Donne tries his hand in poetry to handle such question. Before the conquest, the image of death is described accordingly. In the sequence of Divine Meditation, the apparent image of death is a personified death. Death is often "gluttonous" (sonnet 6, 5). For all living creatures, at least for human being, death is an inevitable destiny. For present knowledge of man, he is bound to die one day. In this material world, many substances dissolve at a time. In a broad sense, it may call the changing or transformation of all things death. The end of or dissolution of one form is death of one thing. So it may say that death comes to everything in this world. Because it destroys all things, it is more like a gluttonous man devouring everything without choice. Besides Christianity, the devourment of death has significant meaning. Frazer (1963) discusses some rites of original tribes. In some New Guinea tribes, a man must perform a ceremony before he is admitted by the tribe as an adult. The novice enters a building in a monster shape after parting his mother and friends. The entering of the building represents that he is devoured by the monster and has died. He is circumcised in it. After several months, he comes back as a young man who is accepted by the tribe (p. 908-9). The devourment resembles the death of the young lad. It is a necessary step of birth of a young man in the tribe. Those people have symbolized death as a process of transforming from one form to anther. Gluttony is the character of man. As death devours everything in the world, he is like a gluttonous person. Besides gluttony, death also has other characters of man.

In sonnet 10, Donne warns "Death be not proud" (1). Being personified, death occupies some characters of man. As destructive power to everything in this world, death may claim itself as dominating the world. It can boast its domination as his pride. According to Christianity, pride is the first sin among seven sins. It causes the fall of angels and men. Before his fall, Satan is a beautiful angel named Lucifer. He is proud of his beauty that he wants to overthrow God and replace him in the heaven. Nevertheless, his rebellion ends with his defeat. He becomes ugly and turns into Satan. Pride causes the end or dissolution of good things. As a "mighty and dreadful" (sonnet 10, 2) power that brings an end to all the things in the world, death is entitled to say he has absolute power over all things, at least for all men or living creatures. If death is proud, its power will dissolve as Satan. It means death itself will disappear. If it is so, death cannot conquer everything in the world because his pride. Though death "think'st" he "doth overthrow" all the people (3), but the actual situation is not what death has supposed. At least, death cannot "kill" Donne himself (4). Donne clearly sees that pride is the dominant character of death. It is reasonable to believe that death will lose some of his powers. With this idea, poet makes sure that he can escape from the hands of death.

Though losing some powers over man, death uses its powers over man. Sometimes, it takes away the "best men" from society when they are young (sonnet 10,7). To the living people, their lives have ended. But in Donne's eyes, it is different. Jesus Christ has been crucified and died. 3 days later, he comes back to life and ascends to heaven. 3 days in the tomb is a rest of his body. For "best men", their death like the death of Christ is "rest of their bones, and soul's delivery" (8). They work hard and perform their duties in the society. Actually death helps them out of their heavy works. After the rest, they arise from rest one day, and live an immortal life in another world.

Sometimes, death is not the roller of the world, but serves as a "slave to fate, chance, kings, and desperate men" (sonnet 10,9). Fate is more powerful than death. No one can change his fate. If he is bound to die, death will take him away at the time appointed. Death does not come earlier or late. It is a servant to the fate. Chance is another dominant power over death. It requires death to take lives at an accident. Kings are the other forces controlling death of man. The lives of men are under the orders of kings. They can decide whether a man to live or die. And desperate men are not afraid of death. They do what they want to do, and do not consider the results of their actions. In other word, when they do anything, they never consider safety of themselves. All the four are the controllers of death.

Sometimes, death lives together with "poison, war, and sickness" (sonnet 10, 10). Poison brings death to a man, and war takes away many people's lives. They are always symbols of death. In sonnet 4, sickness is “death's herald, and champion" (2). When death comes, it needs the help of these three things. If one avoids them, death finds no place in him. So death is not so powerful as one has imagined.

If death is inevitable, it is not fearful. Its "stroke" is worse than "poppy, or charm" (sonnet 10, 11-2). Donne believes death only brings "sleep" to man (13). "Rest and sleep" are images of death (5). After a rest or sleep, man refreshes from his tired situation and has more energy and pleasure. When man comes back from death, he will have more energy and pleasure than what he has gained from rest and sleep. It is not a terrible thing, but a pleasant thing. It is funny that death wants to "swell" (12). It does nothing harm to man but helps him to have more power.

With these characters typical of man, death is not so terrible. It has weakness. Being conscious of this, Donne calls out at the end of sonnet 10, "Death thou shall die" (14). Death is not master of all, but a slave to fate, chance, kings, and desperate men. And the power of killing all people has been weakened because it needs the help of poison, war, and 
sickness. Even when death comes, it is just a long rest or sleep. It does no harm to man. On the contrary, when man revives, death finds no place for itself. There is no death at all. This is a personified death in the poet's mind. With this personified image, poet finds weakness of death, and bids the dissolution of death itself. If a personified death will disappear, how about the dissolution of real death? If death is conquerable, what is death?

Death is the decay of a work - the work of God (sonnet 1,1). It is the inevitable fate of man. Man is the creation of God. As a Christian, Donne believes that the fruit of the tree of knowledge "threw death on else immortal" men (sonnet 9, 2). Before Adam and Eve had eaten the fruit of tree of knowledge, they are immortal in the Garden of Eden. God commanded the man, "You may freely eat of every tree of the garden; but of the tree of the knowledge of good and evil you shall not eat, for in the day that you eat of it you shall die" (Gen. 2. 16-7). As a punishment of disobedience, death falls on Adam and Eve. What kind of death? Having found Adam and Eve eating the fruit of forbidden tree, God said to Adam "you are dust, and to dust you shall return" (Gen. 3. 19). It means that man is made from dust, and will return back to origin when he comes to his end. This death is the dissolution of body. Man's body is mortal since the first fall. "Poison, war, and sickness" bring death to man (sonnet 10,9). They terminate the lives of men. Though the body dies, the soul still exists. Plato (1998) thinks that soul is immortal, while the body disappears (610a-e). Donne believes that one day, when the angels "blow" their "trumpets" (sonnet 7, 1-2), "numberless infinities / Of souls" (sonnet 7, 3-4) will "arise / From death" (sonnet 7, 2-3). When the body dies, soul remains somewhere and is waiting for the last judgment.

Towards death, different Christian theologians hold different opinions. For example, Luther thinks that death has two folds, the temporal one and the eternal one. The temporal death is the separation of body and soul (qtd. in Marius, 1999, p. 105). It means that man is the combination of body and soul. This idea is clearly stated in Bible. Having created the Garden of Eden, God used the dust from ground to form man. Then He breathed into his nostrils the breath of life. Thus came a living man. He is the first man Adam. (Gen. 2.7) As a punishment of disobedience, God commended man to return to dust. It is the dissolution of body. He didn't say anything about the soul. So contrast to immortal soul, body is a mortal thing. What causes death, the dissolution of body? "The wages of sin is death" (Rom. 6.23). It is sin that brings death. Since the first fall, everyman has $\sin$ in him at his birth. So for Donne, it is his "feeble body doth waste / By sin in it" (sonnet 1, 7-8). Sin causes the death of body. In Christianity, there are seven sins, namely pride, covetousness, envy, wrath, gluttony, sloth, and lechery. What kind of sin Donne has? Winny (1981) has mentioned this question, but left it unrevealed (p. 36). Is it the original sin, or the sin mentioned in his love lyric? Donne never says it. Though he has not defined it in his poems, he is so conscious of the sin within him. It may be terrible. Sometimes, "intent or reason", born in him, "make sins" more "heinous" (sonnet 9, 5-6). With the consciousness, he feels that sin is a fearful thing within him. It will cause something worse. Donne thinks he is "a little world made cunningly / Of elements, and an angelic sprite" (sonnet 5, 1-2). This concept reflects the cosmology in Renaissance England. Man is a little universe with properly mixed elements. He has three souls, namely vegetable, animal, and reason. This idea does not conform to the orthodox idea of soul. Donne thinks "both parts must dies" (sonnet 5, 4). It is to say that sin causes the death of both body and spirit of man. If there is the death of spirit, it is the eternal death of man. In Luther's opinion, the eternal death has two folds. One is good; other is a very great evil. The evil death is the death of damned. When man is saved, the man that evil lives forever dies (qtd. in Marius, 1999, p. 106-7). The "black sin hath betrayed to endless night" (sonnet 5, 3). But man's spirit will never die. It must be saved.

Donne thinks his "black soul" is "summoned / By sickness" (sonnet 4, 1-2). It is in a dangerous case before dissolution. The soul is associated with sin. Because of $\sin$, his soul is like a person who betrays his country, and cannot go back to his homeland. Because of sin, it is a thief who wishes to be freed from the prison. This metaphor means since the first fall, man is sinful. The sin will bring death both of body and soul. But soul will never die because it can be saved. The best way of salvation is to wash soul itself "in Christ's blood" (sonnet 4, 13). The blood of Christ is invaluable and "worthy" (sonnet 9, 10). His soul may change from black to red for the blood of Christ "dyes red souls to white" (sonnet 4,14). When black symbols sin, it is not sinful if the soul turns to red. Believing that sin associates with him, Donne wishes to drown his "sin's black memory" (sonnet 9, 12) in "a heavenly lethean flood" (11), which is made of "worthy blood of Christ" and his tears (10). It is another way to drive sin out of man. In one case, the sin of the author is forgotten. In another case, the sin of the author will be washed away by the blood of Christ. It is the grace of God. As the sin is washed away, the soul of author is immortal. He gets the salvation from God through Christ.

Christ is divine as the Son of God. He is also a man, being conceived by the Holy Ghost and born to the Virgin Mary. $\mathrm{He}$ is free from original sin. He was sent by God to atone for the sin of man. He lives as man lives, suffers as man suffers, and dies for man's redemption. As a god, Christ will never die. But as a human being, he is mortal. So with mortal body, Christ can die and pay for the sin of man, and save human being. He is the one who "could do no iniquity" (sonnet 11, 4). When Christ was crucified, his body died. He died for human being, "his creatures, and his foes" (sonnet $12,14)$. So death of Christ is a victory over evil and is blessed by the world.

Death of Christ's body has two meaning. One is he pay for the sin of man. Other is the death of sin and death of death. Luther thinks that death of sin and death of death is an eternal death. When a man dies, his soul separates from sin and body from corruption. Body is the vehicle of sin. When it dissolves, sin perishes with it and returns no more (qtd. in Marius, 1999, p. 106). Christ's body has died, and no sin can usurp it. So the death of Christ is a great victory. It completely defeats the death.

Donne believes that Christ, Son of God, gives him "his death's conquest" (sonnet 16, 4). Nothing can compare with 
the death of Christ. In sonnet 11, Donne orders "Spit in my face ye Jews, and pierce my side, / Buffet, and scoff, scourge, and crucify me" (1-2). With such punishments, it pays for the sins within him. But his suffering is as great as the suffering of Christ because he has sins himself, including original sin. Christ is pure and innocent, and free from original sin. Christ dies for the sin of man, and Donne dies for the sins of him. That is the difference. So Donne is conscious that his death cannot compare with death of Christ. He knows his death cannot satisfy his sins. But with the salvation it seems not enough for Donne. He further calls for the enslavement of God (sonnet 14, 13). He is the battlefield of God and Evil. With the occupation of God, he can defeat death and has an eternal life.

With those ideas in his mind, Donne never thinks that his wife is really dead. Though her body dissolved in this world, but she is "ravished" into heaven (sonnet 17, 3), where she is immortal. As death of Christ has paid the sin of her, "Devil put" her "out" (14). Her death is the death of body in this world, and her spirit is immortal in another world, or in the heaven.

Though the sequence of Divine Meditation is the arrangement of editor, the concept of death and sin shares some common grounds and connections. Donne discusses death from different angles and aspects. It reflects Donne's conception of death as a Christian. He firmly believes that the death is the dissolution of body, and the death of sin and death. Eventually, he confirms that with God's grace and the death of Christ, man's soul is saved. Man defeats death and gains an eternal life with the grace of God.

\section{REFERENCES}

[1] Abrams, M. H. Ed. (1993). The Norton anthology of English literature. 6th ed. Vol. 2. New York: Norton.

[2] Brooks, Cleanth. (1947). The well wrought urn: studies in the structure of poetry. New York: Harcourt, Brace and World, Inc.

[3] Bush, Douglas. (1962). English literature in the early seventeenth century: 1600-1660. 2nd ed. London: Oxford University Press.

[4] Car-Gomm, Sarah. (1995). The dictionary of symbols in western art. New York: Facts On File.

[5] Ford, Boris. Ed. (1957). From Donne to Marvell. The Pelican guide to English literature. 3. Middlesex, England: Penguin Books.

[6] Frazer, James George. (1963). The golden bough: a study in magic and religion. Abridged. Ed. London: MacMilan and Co. Ltd..

[7] Heidegger, Martin. (1999). Being and time. Trans. John Macquarrie and Edward Robinson. Beijing: China Social Science Publishing House and Chengcheng Books Ltd.

[8] Holy Bible: New Revised Standard Version (2000). National TSPM \& CCC.

[9] Marius, Richard. (1999). Martin Luther: the Christian between God and death. Massachusetts: The Belknap Press of Harvard University Press.

[10] Plato. (1998). Republic. Trans. John Llewelyn Davies, and David James Vaughan. Beijing: Foreign Language Teaching and Research Press.

[11] Smith, A. J. Ed. (1982). John Donne: the complete English poems. Middlesex, England: Penguin Books Ltd.

[12] Stokstad, Marilyn. (1995). Art history. Vol. I. New York: Prentice Hall, Inc., and Harry N. Abrams, Inc.

[13] Winny, James. (1981). A Preface to Done. Revised ed. London: Longman.

Dini Zhang was born in Huaiyang, Henan Province, China in 1982. She received her M. A. degree in literature from Hunan University, China in 2008.

She is currently a lecturer in English Department of Literature and Law School, Sichuan Agricultural University, China. Her research interests include English literature and American literature.

Dingming Wang was born in Qionglai, Sichuan Province, China in 1975. He received his M. A. degree in literature from Southwest University, China in 2007.

He is currently a lecturer in English Department of Literature and Law School, Sichuan Agricultural University, China. His research interests include English literature and American literature. 